\title{
A Tracer Study on the Employability of Information Technology Graduates of Ilocos Sur Polytechnic State College, Tagudin Campus
}

\author{
George R. Villanueva Jr. ${ }^{1}$, Lito W. Binay-an² \\ ${ }^{1}$ College of Arts and Sciences, Ilocos Sur Polytechnic State College \\ ${ }^{2}$ College of Teacher Education, Ilocos Sur Polytechnic State College \\ Tagudin, Ilocos Sur, Philippines \\ Email:1'geovilla2576@ispsc.edu.ph, ${ }^{2}$ mistrotolits@gmail.com
}

\begin{abstract}
The purpose of the study was to examine the employability of the Information Technology graduates of Ilocos Sur Polytechnic State College Tagudin Campus in the Philippines. A survey questionnaire was administered to the graduates from the year 2012 to $2016(\mathrm{n}=152)$. In general, about 53 percent of those who participated in the survey were employed while the rest were employed but stopped (26 percent) and never employed (21 percent). Although most of the graduates were employed, many of them are in jobs that are not related to their course. The main reasons identified for those who stopped from their work include end-of-contract, starting pay is too low, and plans to seek jobs abroad. The graduates' employment barriers include lack of work experience, professional eligibility, and intent to seek employment abroad. More than 50 percent recommended that the computer facilities used by the IT students should be upgraded to improve the employability of the IT graduates.
\end{abstract}

Keywords

employability;information technology;graduates; tracer sttudy

Article Received: 10 August 2020, Revised: 25 October 2020, Accepted: 18 November 2020

\section{Introduction}

There are several motives for pursuing higher education. For some, it is a stepping stone towards a decent career and the chance to experience a different way of life. However, finishing higher education is not a guarantee because education institutions are often criticized by employers for not preparing the graduates against those required to be competitive in a job setting [1,2]. Employers expect graduates to have technical and discipline competencies from their degree and possess a broad range of employability skills who can work flexibly and intelligently in the organization [3].

In the context of higher education, employability is characterized as a set of skills, expertise, and personal qualities that make an individual more employable and competitive in their chosen occupations, which benefits themselves, the community, and the economy [4]. Globally, higher education institutions are evaluating the approaches they use to increase students' employability and are taking numerous steps to grow and enhance them. Talley [5] reemphasized the importance of higher education in preparing students for the world of work. Higher education needs to review and further develop the opportunities it makes available to its students to consider entrepreneurship and self-employment as an option upon graduation.

In the Philippines, the educational attainment of the Filipino population has steadily increased in recent decades, but while the country is regionally successful, issues of skills shortage were the primary reason why vacancies were difficult to fill in 2012. Similarly, based on the data commissioned by the World Bank Enterprise Survey, firms disclosed that socio-behavioral skills, such as managerial, leadership, interpersonal and effective communication skills are difficult to find in potential employees. Employers have continued to emphasize the importance for the graduates to possess the required mix of these skills [6,7].

To align theory and reality in the curriculum, the Commission and Higher Education (CHED) in the Philippines has mandated universities and colleges to have an industry relationship. Although many institutions have adopted the principle of academe-industry partnership in the Philippines, both private and public, job mismatch remains a critical concern. According to the study of Moya [8], there are three leading causes of jobs-skills mismatch among the graduates: 1) weak labor-market information systems; 2) job seeker's career preference is no longer in-demand; and 3 ) inadequate preparation in terms of education, training, and guidance.

To address the job mismatch and enhance the graduates' employability, particularly in the field of Information Technology (IT), CHED has embedded on-the-job training (OJT) in the Philippines' IT curriculum. The internship aims to provide IT students with an opportunity to complement their formal learning with real industry settings, acquire soft skills, and develop professional work ethics [9]. Holmes [10] noted that collaboration between HEIs and employers are important in promoting work-based learning and producing professional skills which they need in order to be successful in their fields.

Despite the inclusion of the internship into the Information Technology Education (ITE) curriculum, its implementation has some shortcomings. The study of Verecio [11] stated that OJT students were deployed to workplaces that are not related to their specialization; thus, the OJT students do not acquire the technical knowledge within their industry. Also reported in the study is the limited number of IT-related sectors that are available in the region, which causes the OJT students to non-related IT industry.

In this context, this study aimed to determine the employability of the IT graduates of Ilocos Sur Polytechnic 
State College (ISPSC), Tagudin Campus from academic year 2011 to 2016. These graduates are considered the pioneer batch since the campus offered an IT course. They have also experienced in-campus and off-campus on-the-job training from various establishments in the region. Further, this study sought the recommendations of the graduates on how to improve the competencies and skills of the students to enhance their long-term employability.

\section{Research Methods}

The study adopted a descriptive survey design. A research questionnaire patterned from previous trace studies was administered to the IT graduates from year 2012 to 2016. The survey aimed to assess the employability of the IT graduates of Ilocos Sur Polytechnic State College (ISPSC), Tagudin Campus. Specifically, it looked into the relatedness of the course to their work; the reasons why they stopped from work; and why they are never employed. The study also solicited the graduates' opinions on the possible strategies to enhance the competitive edge of ISPSC IT graduates.

ISPSC, Tagudin Campus is one of the six campuses of ISPCS located in the second district of Ilocos Sur. The campus offers junior and senior high schools, ten baccalaureate programs, and two master's programs. It is mandated to provide professional and technical training both in the undergraduate and graduate courses. A total of 152 graduates completed the survey representing a 42.10 percent response rate. Table 1 summarizes the distribution of participants $(\mathrm{n}=152)$ from year 2012 to 2016 .

Descriptive statistics such as frequency, percentage, and rank were used to describe the employability of the graduates.

Table 1. Distribution of Respondents

\begin{tabular}{|l|l|l|}
\hline Year Graduated & Frequency & Percentage \\
\hline 2012 & 22 & $14.47 \%$ \\
\hline 2013 & 35 & $23.03 \%$ \\
\hline 2014 & 29 & $19.08 \%$ \\
\hline 2015 & 36 & $23.68 \%$ \\
\hline 2016 & 30 & $19.74 \%$ \\
\hline Total: & 152 & $100 \%$ \\
\hline
\end{tabular}

\section{Results And Analysis}

This section presents the data collected from the study.

As indicated in Table 2, of the total, about 53 percent were presently employed while the rest were employed but stopped ( 26 percent) and never employed ( 21 percent). The large number of employed graduates could be attributed to the high employment rate ( 94.5 percent) in the region in 2016, which provides job opportunities even for fresh graduates (Philippine Statistics Authority, 2016). Alternatively, higher education needs to study and create opportunities for the students to consider entrepreneurship and self-employment as an option upon graduation so that graduates do not rely on job vacancies (Moreland, 2006).
Table 2. Employment Status

\begin{tabular}{|l|l|l|}
\hline Employment Status & Frequency & Percentage \\
\hline Presently employed & 80 & 53 \\
\hline Employed but stopped & 40 & 26 \\
\hline Never employed & 32 & 21 \\
\hline Total & 152 & $100 \%$ \\
\hline
\end{tabular}

As shown in Table 3, of those who were presently employed, more than half (52.5 percent) indicated that their job was not related to their course, while the rest $(47.5$ percent) indicated that their work was related. In a study conducted by Montt [14], a field-of-study mismatch occurs when a worker trained in a specific field works in another. The research concluded that workers who cannot find employment in their field-of-study might have to accept jobs below their qualifications or potential level. In effect, fieldof-study mismatch entails lower-income, an increased risk of unemployment, and lower work satisfaction levels.

Table 3. Relatedness of the Course to their Work

\begin{tabular}{|l|l|l|}
\hline Indicators & Frequency & Percentage \\
\hline Related to course & 38 & $47.5 \%$ \\
\hline Not related to course & 42 & $52.5 \%$ \\
\hline Total & 80 & $100 \%$ \\
\hline
\end{tabular}

The survey also asked the respondents the reasons why the once employed graduates stopped from their work. It is clear from the data in Table 4 the three leading reasons were endof-contract, starting pay is too low and plans to seek jobs abroad. Unsurprisingly, the end-of-contract was the main reason for ending their work since most of these employed graduates were temporary or contractual. Although end-ofcontract is allowed in the constitution under the Labor Code of the Philippines, it must harness its young graduates' potentials by providing sustainable and decent jobs because they offer opportunities to boost the country's economic growth [15].

Table 4. Reasons why the IT Graduates Stopped from their Work

\begin{tabular}{|l|l|l|}
\hline Reasons & Frequency & Rank \\
\hline End-of-contract & 20 & 1 \\
\hline Starting pay is too low & 16 & 2 \\
\hline Have plans to seek jobs abroad & 04 & 3 \\
\hline Total & 40 & \\
\hline
\end{tabular}

As shown in Table 5, the three leading reasons why the IT graduates were never employed were lack of experience, lack of professional eligibility, and plans to seek jobs abroad. According to Lees [16], employers value graduates who have an understanding of how businesses operate. HEIs should well manage work experience opportunities for the students through partnerships with employers to be educationally valuable. Holmes [10] suggested that if work experience is not a formal part of the degree program, students' tasks should promote work-based learning. Similarly, Knight and Yorke [17] noted that one way to increase graduates' competitiveness in the labor market is to design job attachments into the degree programs. This line of thought agrees with Abelha et al. [18] that employability could be further improved by incorporating work experience into the curriculum and by inviting employers as guest lecturers in student activities. 
Table 5. Reasons why the IT Graduates were Never Emloyed

\begin{tabular}{|l|l|l|}
\hline Reasons & Frequency & Rank \\
\hline Lack of work experience & 21 & 1 \\
\hline Lack of professional eligibility & 09 & 2 \\
\hline Have plans to seek jobs abroad & 02 & 3 \\
\hline Total & 32 & \\
\hline
\end{tabular}

The respondents were asked to identify or suggest recommendations that they think will improve the IT graduates' employability. Table 6 shows the recommendations of the graduates such as upgrading the facilities, 'employing competitive faculty, 'limiting the number of students enrolled per class', 'prioritizing the faculty development', and 'reviewing/updating the curriculum'. More than 50 percent recommended that the computer facilities used by the IT students should be upgraded to improve the employability of the IT graduates.

The respondents perceived the importance of having adequate facilities and resources affect their learning because most IT students rely on computer laboratories to accomplish their case studies. Glenn [19] noted that higher education should plan and train future workers with emerging technologies as these technological advances will change future workers' skill-sets. Equally important to the graduates' soft skills, their technical skills needed in the workplace should be reflected in the curriculum and course design [20]. Therefore, it is necessary for the institution to enhance the IT facilities and infrastructures for the students' skills development to help them later define their career goals, entrepreneurship, and job opportunities.

Table 6. Strategies to Enhance the Competitiveness of the IT Graduates

\begin{tabular}{|l|l|l|}
\hline Strategies & Frequency & Rank \\
\hline Upgrade facilities & 56 & 1 \\
\hline Employ only competitive faculty & 35 & 2 \\
\hline $\begin{array}{l}\text { Limit the number of students per } \\
\text { class }\end{array}$ & 32 & 3 \\
\hline $\begin{array}{l}\text { Give priority to faculty development } \\
\text { and appropriate budget }\end{array}$ & 27 & 4 \\
\hline Review and update to curriculum & 20 & 5 \\
\hline
\end{tabular}

Employing competitive faculty appears to come after the upgrade of facilities in terms of frequency. The CHED mandates teachers of tertiary schools to finish a postgraduate degree to become tenured or regular employees. Such will ensure that only eligible individuals with relevant academic knowledge and teaching abilities are allowed to teach. Knight and Yorke [17] concluded in their study that teachers are expected to conduct their subjects aligned with the planned program learning environment's curricular intentions. Faculty members should design curriculum and pedagogy in a manner that increases graduate employability [21].

\section{Conclusion}

Higher education institutions' contribution to employability can be appraised by looking at employment rates of its graduates. The results indicated that the majority of the IT graduates of ISPSC, Tagudin Campus were employed.
However, many of these graduates are into jobs not aligned to their field of specialization. The reasons for those who stopped from their work include end-of-contract, starting pay is too low and plans to seek jobs abroad. The graduates' employment barriers include lack of work experience, professional eligibility, and intent to seek employment abroad.

The institution should consider the recommendations of the graduates such as improvement of the IT facilities used by the students, employing qualified and competent faculty, limiting the number of students per class, prioritizing the faculty development, and updating of the curriculum of the course to improve the employability of the graduates.

\section{References}

[1] C.P. Garcia, and M. Barac, "Promoting Employability in Higher Education: A Case Study on Boosting Entrepreneurship Skills", Sustainability 2020, vol. 12, issue 19, May 14, 2020.

[2] B. D. L. Harpe, A. Radloff, and J. Wyber, "Quality and Generic (Professional Skills)", Quality in Higher Education,vol.6, issue 3, 2010. DOI: 10.1080/13538320020005972.

[3] K. Lowden, S. Hall, D. Elliot, and J. Lewin, "Employers' Perceptions of the Employability Skills of New Graduates", University of Glasgow SCRE Centre and Edge Foundation 2011. Available: https://www.educationandemployers.org/w pcontent/uploads/2014/06/employability_sk ills_as_pdf_-_final_online_version.pdf

[4] M. Yorke, "Employability in Higher Education: what it is - what it is not", Higher Education Academy, York, England, $2006 . \quad$ Available: https://www.advance-he.ac.uk/knowledgehub/employability-higher-education-whatit-what-it-not

[5] P.C. Talley, "Preparing Students for the Globalized Workforce: A Mission Statement for Taiwanese Universities", International Journal of Humanities and Social Science, vol. 7, no. 3, March 2017.

[6] OECD/ADB (2017), "Employment and Skills Strategies in the Philippines, OECD Reviews on Local Job Creation", OECD 
Publishing, Paris. Available: https://doi.org/10.1787/23112336

[7] The Word Bank (March 30, 2017), "Philippines - Enterprise Survey 2015 “, Available:

https://microdata.worldbank.org/index.php /catalog/2800

[8] J.R. Moya, "Job-skills mismatch in the Philippines and the Advent of Industry 4.0". Available: https://www.fsi.gov.ph/wpcontent/uploads/2018/02/JRAM-JobSkills-Mismatch-Mabini-Dialogue.pdf

[9] CMO No 25, Series of 2015. "Revised Policies, Standards, and Guidelines for BSCS, BSIS, and BSIT Programs". Available: https://ched.gov.ph/cmo-25-s2015/

[10] L. Holmes, "Reconsidering Graduate Employability: The 'Graduate Identity' Approach", Quality in Higher Education, vol. 7, no. 2, 2011.

[11] R. L. Verecio, “On-the-Job Training of the BS Information Technology Program of Leyte Normal University, Tacloban City: An Assessment. International Journal of Education and Research, vol. 2, no. 3, March 2014.

[12] Philippine Statistics Authority, "2016 Annual Labor and Employment Status". Available:

https://psa.gov.ph/content/2016-annuallabor-and-employment-status

[13] N. Moreland, "Entrepreneurship and Higher Education: An Employability Perspective, Learning and Employability Series 1 ", The Higher Education Academy, York, 2006.

[14] G. Montt, "The causes and consequences of field-of-study mismatch: An analysis using PIACC", OECD Social, Employment and Migration Working Papers, no. 167, OECD Publishing, Paris. Available:

https://doi.org/10.1787/5jrxm4dhv9r2-en.

[15] MC.M. Tolentino, "Philippine Report on Employment Trends and Policies: Can Duterte Administration End
Contracualization?". Japan Labor Issues, vol 1, no. 3, Nov- Dec 2017.

[16] D. Lees, "Graduate Employability Literature Review", LTSN Generic Centre, October 2002. Available: https://www.qualityresearchinternational.c om/esecttools/esectpubs/leeslitreview.pdf

[17] P.T. Knight, and M. Yorke, "Employability and Good Learning in Higher Education", Teaching in Higher Education, vol. 8, no. 1, 2003.

[18] M. Abelha, S. Fernandes, D. Mesquita, F. Seabra, and A. T. Ferreira-Oliveira, "Graduate Employability and Competence Development in Higher Education - A Systematic Literature Review Using PRISMA”, Sustainability 2020, vol. 12.

[19] M. Glenn, “The Future of Higher Education: How Technology Will Shape Learning", Economist Intelligent Unit, October 2008, Available: https://files.eric.ed.gov/fulltext/ED505103. pdf

[20] I. M. Suarta, I. K. Suwintana, I.G.P.F.P. Sudhana, and N.K.D. Hariyanti, "Employability Skills Required by the 21st-century Workplace: A Literature Review of Labour Market Demand", Advances in Social Science, Education and Humanities Reseach, vol. 2, 2017.

[21] E. G. T. Sumanasiri, M. S. A. Yajid, and A. Khatibi, "Conceptualizing Learning and Employability Learning and Employability Framework", Journal of Education and Learning, vol.4, no. 2, 2015. 